Al-Huquq: Journal of Indonesian Islamic Economic Law, 2 (2), 2020: 175-192

ISSN: 2715-0003; E-ISSN 2714-5514

DOI: http://dx.doi.org/10.19105/al-huquq.v li2.3208

\title{
Konsep Rukhsoh dan Relevansinya dengan Kaidah Al-Masyaqqah Tajlib Al-Taysir (Studi Kasus pada Peraturan OJK Nomor 11/POJK.03/2020 dan Surat Edaran Nomor S- 9/D.05/2020)
}

\author{
Camelia Rizka Maulida Syukur \\ (Universitas Islam Indonesia, Jl. Kaliurang Km. 14,5 \\ Umbulmartani, Ngemplak, Sleman, Yogyakarta, 55584)
}

\begin{abstract}
:
Penyebaran penyakit coronavirus 2019 (COVID-19) secara global telah berdampak langsung maupun tidak langsung terhadap stabilitas makro dan mikro ekonomi, termasuk Indonesia. Dalam hal ini pemerintah sebagai amri dan para pemangku kepentingan diperbolehkan untuk membuat kebijakan sebagai bentuk takhfif (keringanan) kepada masyarakat sebagai bentuk stimulus bagi masyarakat yang terkena dampak Covid-19 sebagaimana diatur dalam Peraturan OJK Nomor 11 / POJK.03 / 2020 dan Nomor Edaran S-9 / D.05 / 2020. Penelitian ini merupakan penelitian kualitatif dan metode yang digunakan dalam penelitian ini adalah metode penelitian kualitatif deskriptif dan juga melalui metode langsung maupun tidak langsung. Sumber data yang digunakan adalah data sekunder eksternal yang diperoleh secara tidak langsung melalui perantara, seperti orang lain atau buku referensi dokumen terkait. Metode analisis data menggunakan teknik analitik sehingga mampu menjawab dan mengkorelasikan permasalahan kontemporer dengan teks jika ditemukan, dan melalui kesepakatan ulama jika diperlukan. Kesimpulan yang didapat adalah melihat bahwa Islam menjunjung tinggi nilai kemanusiaan, bahkan pemeliharaan jiwa lebih penting dari pada pemeliharaan agama itu sendiri dan kondisi terkini yang menyangkut keselamatan dan kepentingan banyak orang. Ketika ada dharurah, hukum yang diambil ringan, demikian pula ketika ditemukan masyaqqah (kesulitan) maka mengambil rukhsoh diimbangi dengan melakukan 'azimah. Dalam hal ini pemerintah sebagai amri dan para pemangku kepentingan diperbolehkan untuk membuat kebijakan sebagai bentuk takhfif (keringanan) kepada masyarakat sebagai bentuk stimulus bagi masyarakat
\end{abstract}

email koresponden:nurhidayah.marsono@gmail.com https://creativecommons.org/licenses/by-nc/4.0/ Copyright (c) 2019 by al-huquq. All Right Reserved 
yang terkena dampak Covid-19 sebagaimana diatur dalam Peraturan OJK Nomor 11 / POJK.03 / 2020 tentang stimulus ekonomi nasional sebagai kebijakan countercycial terhadap dampak penyebaran penyakit coronavirus 2019 dan Surat Edaran Nomor S-9 / D.05 / 2020 tentang kebijakan countercyclical terhadap dampak penyebaran penyakit coronavirus (Covid-19) bagi perusahaan keuangan. (The spread of coronavirus disease 2019 (COVID-19) globally has had a direct or indirect impact on macro and microeconomic stability, including Indonesia. In this case the government as amri and the stakeholders are allowed to make policies as a form of takhfif (relief) for the community as a form of stimulus for covid-19 impact communities as stipulated in OJK Regulation Number 11/POJK.03/2020 and Circular Number S-9/D.05/2020. This research is a qualitative research and the method used in this study is a descriptive qualitative research method and also through direct or indirect methods. Data sources used are external secondary data obtained indirectly through intermediaries, such as other people or relevant documents reference books. The method of data analysis uses analytical techniques so that they are able to answer and correlate contemporary problems with texts if found, and through the scholars' agreement if necessary. The conclusion obtained is to see that Islam upholds the value of humanity, even the maintenance of the soul is more important than the maintenance of religion itself and the current conditions concerning the safety and interests of many people. When there is dharurah, the law that is taken is light, and likewise when it is found masyaqqah (difficulty) then taking rukhsoh is balanced by doing 'azimah. In this case the government as amri and the stakeholders are allowed to make policies as a form of takhfif (relief) for the community as a form of stimulus for covid-19 impact communities as stipulated in OJK Regulation No. 11/POJK.03/2020 concerning national economic stimulus as a countercycial policy on the impact of the spread of coronavirus disease 2019 and Circular Letter Number S-9/D.05/2020 concerning countercyclical policies on the impact of the spread of coronavirus disease (Covid-19) for finance companies.)

Keyword:

rukhsoh, al-masyaqqah, kebijakan dan stimulus 
Konsep Rukhsoh dan Relevansinya

dengan Kaidah Al-Masyaqqah Tajlib Al-Taysir

\section{Pendahuluan}

Perkembangan penyebaran coronavirus disease 2019 (COVID19), selain dampaknya pada sektor publik, perusahaan maupun perkantoran, virus corona juga memberi dampak terhadap individu/perorangan. Sehingga, sebagai makhluk ciptaan Allah swt sekaligus makhluk sosial, manusia akan mengalami perasaan sedih dan khawatir mengahadapi kondisi saat ini. Islam, sebagai agama yang rahmatan lil 'alamin memberikan perhatian besar terhadap unsurunsur kesulitan yang dialami umatnya. Syari'at Islam menjaga sebuah prinsip menghilangkan kesulitan dengan kaidah baku dan dasar permanen yang dapat dijadikan media penyimpulan hukum (istinbath) ketika tidak ditemukan dalil syar'i. Allah swt sebagai Musyarri' yang Maha Kuasa, dengan kekuasaan-Nya mampu menundukkan ketaatan manusia untuk mengabdi kepada-Nya. Supaya dalam realisasi penghambaan itu tidak terjadi kesalahan maka, Allah swt membuat aturan-aturan khusus yang disebut sebagai syari'ah demi kemaslahatan manusia itu sendiri. Barang tentu, aturan-aturan tersebut disesuaikan dengan tingkat kemampuan dan potensi yang dimiliki seorang hamba, karena pada dasarnya syari'at itu bukan untuk kepentingan Tuhan melainkan untuk kepentingan manusia itu sendiri.

Dalam hal ini, Allah swt memberikan 3 alternatif bagi perbuatan manusia, yakni positif (wajib), cenderung positif (sunnah), cenderung negatif (makruh) dan negatif (haram). Untuk realisasi kelima alternatif itu selanjutnya Allah swt memberikan hukum keharusan yang disebut dengan 'azimah yakni keharusan untuk melakukan yang positif dan keharusan untuk meninggalkan yang negatif. Namun tidak semua keharusan itu dapat dilakukan manusia, mengingat potensi atau kemampuan yang dimiliki manusia berbedabeda. Dalam kondisi ini, Allah swt memberikan hukum rukhsoh yakni keringanan tertentu dalam kondisi tertentu pula. Sehingga dapat dikatakan bahwa keharusan untuk melakukan 'azimah seimbang dengan kebolehan mengambil rukhsoh. ${ }^{1}$

Berbicara masyaqqah dan rukhsoh, akan sangat relevan jika dikaitkan dengan kondisi saat ini yang serba sulit, bukan hanya di

\footnotetext{
${ }^{1}$ Mukhlis Usman, Kaidah-Kaidah Ushuliyah Dan Fiqhiyah (Jakarta: PT Raja
} Grafindo Persada, 1997)., hlm. 124. 
Indonesia, namun hampir di seluruh dunia, yakni muncul dan masifnya penyebaran virus covid-19. Kondisi ini memberi dampak pada hampir semua lini dan sektor kehidupan, terutama pada sektor ekonomi. Perkembangan penyebaran coronavirus disease 2019 (COVID19) secara global telah berdampak secara langsung ataupun tidak langsung terhadap stabilitas makro maupun mikro ekonomi, termasuk Indonesia. Salah satu dampak yang dirasakan pada kinerja dan kapasitas debitur dalam memenuhi kewajiban pembayaran kredit atau pembiayaan. Oleh karena itu, Otoritas Jasa Keuangan (OJK) mengeluarkan ketentuan lanjutan relaksasi kredit dalam rangka meredam dampak negatif penyebaran virus corona. OJK merilis ketentuan lanjutan restrukturisasi kredit bagi perusahaan leasing seperti tertuang dalam Surat Edaran Nomor S9/D.05/2020 tentang Kebijakan Countercyclical Dampak Penyebaran Coronavirus Disease (Covid-19) bagi Perusahaan Pembiayaan.

Ketentuan tersebut merupakan kelanjutan dari kebijakan stimulus di Industri Keuangan Non Bank ( IKNB ) untuk menjaga stabilitas sektor keuangan dan mendorong pertumbuhan ekonomi. Ketentuan restrukturisasi lebih lanjut ini menyebutkan kelonggaran kredit bisa diberikan kepada debitur yang terkena dampak wabah virus korona dengan plafon pembiayaan paling banyak Rp10 miliar. Pemberian kelonggaran bisa didasarkan pada ketepatan pembayaran pokok/ bunga/ margin/ bagi hasil. Kebijakan restrukturisasi atau countercyclical ini berbunyi bahwa setiap perusahaan leasing dapat memberikan restrukturisasi kredit kepada pihak-pihak yang terkena dampak dengan memenuhi beberapa ketentuan. Yakni adanya proses kebijakan restrukturisasi dari pemberi pinjaman, bagi sumber pendanaan dalam bentuk executing, serta adanya proses dan kebijakan restrukturisasi dari pihak pemilik dana yang dilaksanakan melalui joint financing dan channeling. ${ }^{2}$

Otoritas Jasa Keuangan menilai stabilitas sektor jasa keuangan sampai Maret masih dalam kondisi terjaga dengan intermediasi

\footnotetext{
${ }^{2}$ Deputi Komisioner Humas dan Logistik, SIARAN PERS: STABILITAS SEKTOR JASA KEUANGAN TETAP TERJAGA DI TENGAH MEREBAKNYA WABAH VIRUS CORONA (Jakarta, 2020), https://www.ojk.go.id/id/berita-dan-kegiatan/siaranpers/Pages/Siaran-Pers-Stabilitas-Sektor-Jasa-Keuangan-Tetap-Terjaga-di-TengahMerebaknya-Wabah-Virus-Corona.aspx.
} 
Konsep Rukhsoh dan Relevansinya dengan Kaidah Al-Masyaqqah Tajlib Al-Taysir

sektor jasa keuangan masih membukukan kinerja positif dan profil risiko industri jasa keuangan tetap terkendali meski perekonomian tertekan akibat merebaknya virus Corona di banyak negara. OJK sejak Februari lalu juga telah mengeluarkan berbagai kebijakan stimulus perekonomian di sektor perbankan, pasar modal dan industri keuangan non bank yang diharapkan menjadi countercyclical dampak penyebaran virus Corona sehingga bisa mendorong optimalisasi kinerja industri jasa keuangan khususnya fungsi intermediasi, menjaga stabilitas sistem keuangan, dan mendukung pertumbuhan ekonomi. OJK senantiasa memantau perkembangan ekonomi global yang sangat dinamis dan berupaya untuk terus memitigasi potensi resiko yang ada terhadap kinerja sektor jasa keuangan domestik. ${ }^{3}$

Berbagai kebijakan yang dikeluarkan oleh pemerintah melalui lembaga-lembaga pemangku kepentingan, salah satunya OJK merupakan upaya untuk membantu dan memberi kemudahan bagi masyarakat untuk bisa mengatasi kondisi serba sulit (masyaqqah) seperti saat ini. Prinsip kemudahan dalam diskursus pemikiran hukum Islam begitu banyak, namun penulis mencukupkan diri dengan membahas kaidah-kaidah cabang dari kaidah al-masyaqqah tajlibu al-taysir sebagai perincian dari kaidah ketiga dalam pembahasan qawaid fighiyah, relevansinya dengan konsep rukhsoh dan implikasinya pada Peraturan OJK Nomor 11/POJK.03/2020 dan Surat Edaran Nomor S-9/D.05/2020 sehingga masalah yang akan dibahas yakni "bagaimana penerapan Peraturan OJK Nomor 11/POJK.03/2020 dan Surat Edaran Nomor S-9/D.05/2020 relevansinya dengan konsep rukhsoh pada kaidah al-masyaqqah tajlibu al-taysir?".

\section{Metodologi}

Penelitian ini fokus pada relevansi antara konsep rukhsoh dengan kaidah al-masyaqqah tajlib al-taysir serta implikasinya pada kondisi yang sedang saat ini ramai diperbincangkan, yakni masifnya penyebaran covid-19, sehingga memaksa pemerintah selaku pemangku kepentingan mengeluarkan stimulus-stimulus di segala sektor bagi masyarakat. Seperti yang tertuang dalam Peraturan OJK

\footnotetext{
${ }^{3}$ Ibid., hlm. 1.
} 
Nomor 11/POJK.03/2020 tentang stimulus perekonomian nasional sebagai kebijakan countercycial dampak penyebaran coronavirus disease 2019 dan Surat Edaran Nomor S-9/D.05/2020 tentang kebijakan countercyclical dampak penyebaran coronavirus disease (Covid-19) bagi perusahaan pembiayaan. Sehingga peneliti tergelitik untuk mengangkatnya menjadi topik dalam penelitian ini.

Penelitian ini merupakan penelitian kualitatif dan metode yang digunakan dalam penelitian ini adalah metode penelitian deskriptif kualitatif karena peneliti ingin menggambarkan atau melukiskan fakta-fakta atau keadaan ataupun gejala yang tampak di lapangan pada kebijakan-kebijakan yang dikeluarkan pemerintah dikaitkan dengan Peraturan OJK Nomor 11/POJK.03/2020 dan Surat Edaran Nomor S-9/D.05/2020 melalui metode langsung maupun tidak langsung, serta relevansinya dengan konsep rukhsoh dalam kaidah al-masyaqqah tajlib al-taysir. Sumber data yang digunakan adalah data sekunder eksternal yang diperoleh peneliti secara tidak langsung melalui perantara, seperti orang lain atau dokumen/buku referensi yang relevan. Metode analisis data menggunakan teknik analisis sehingga mamppu menjawab dan mengkorelasikan masalahmasalah kontemporer dengan nash-nash jika ditemukan, dan melalui ijthad ulama' jika diperlukan.

\section{Konsep Masyaqqah}

Kata al masyaqqah berasal dari syaqqa-yasyuqqu yang berarti alta $b u$ atau letih, syaqq juga berarti al-juhdu yang berarti usaha kerja keras. Sebagaimana dalam al-Qur'an surat al-Nahl ayat 7 yang berbunyi:

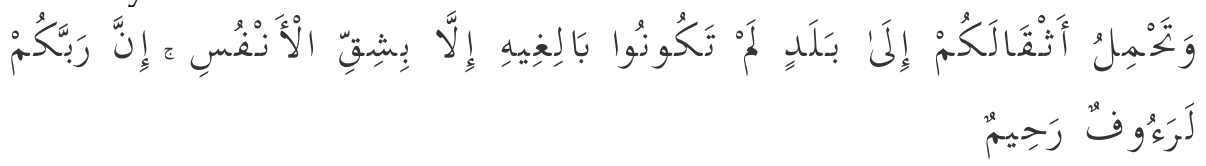

Artinya: "Dan ia memikul beban-bebanmu ke suatu negeri yang kamu tidak sanggup sampai kepadanya, melainkan dengan kesukaran-kesukaran (yang memayahkan) diri. Sesungguhnya Tuhanmu benar-benar Maha Pengasih lagi Maha Penyayang." 
Konsep Rukhsoh dan Relevansinya dengan Kaidah Al-Masyaqqah Tajlib Al-Taysir

Sedangkan kata al-taysir secara bahasa adalah kemudahan dan kelembutan, kejinakan yang berarti al-samhah (toleransi), yusr sendiri adalah kebalikan dari 'asr (kesusahan). ${ }^{4}$

Adapun makna al-masyaqqah yang mendatangkan kepada kemudahan (taysir) yaitu kesukaran-kesukaran yang melewati batas kebiasaan yang keluar dari kemampuan manusia. Kesukaran dalam hal ini tidaklah bersifat mutlak untuk semua bentuk kesukaran, karena semua orang akan mengalami kesusahan dan kesukaran dalam hidupnya. Kesukaran di sini hanya pada hal-hal yang bersifat mencegah kepudaran ataupun eksistensi jika tetap menjalankan perintah. ${ }^{5}$

Syarat-syarat dalam kriteria al-masyaqqah yang menarik kepada kemudahan adalah sebagai berikut: ${ }^{6}$

1. Kesukaran itu tidak bertentangan dengan teks, maka apabila berbenturan dengan teks diambil alternatif yang lain. Dengan demikian, ketika terdapat hukum sesuatu yang telah ditetapkan nash dan di dalamnya terdapat kesukaran maka kaidah ini ditangguhkan dan menggunakan alternatif lain yang tidak membentur nash. Nash di sini adalah baik al-Qur'an maupun al-Hadits.

2. Kesukaran itu merupakan sesuatu yang sudah di luar batas kebiasaan

3. Kesukaran itu bukanlah sesuatu yang tidak bisa terlepas dari ibadah seperti kesukaran yang dirasakan hanya karena capek atau lelah dalam menjalankan ibadah, maka hal ini dihukumi tidak dapat menarik kemudahan atau keringanan dalam meninggalkan kewajiban.

4. Kesukaran itu bukanlah sesuatu yang tidak bisa terlepas dari ketentuan-ketentuan syara' seperti kesukaran dalam jihad, rajam zina dan lain-lain.

Kemudahan dalam bahasa arabnya adalah taysir, secara bahasa berasal dari masdar yusr (mudah). Dan yusr makna bahasanya

\footnotetext{
${ }^{4}$ Muhammad Shidqi bin Ahmad Al-Burnu, Al-Wajiz Fi Idhahi Qawaid Al-Fiqh AlKulliyah (Beirut: Muassisah al-Risalah, 1996), hlm. 92.

${ }^{5}$ Muhammad Shidqi bin Ahmad Al-Burnu, Mausuah Al-Qawaid Al-Fiqhiyah, 9th ed. (Beirut: Muassisah al-Risalah, 2003)., hlm. 632.

${ }^{6}$ Muhammad Al-Zuhaili, Al-Qawaid Al-Fiqhiyah Wa Tathbiqatuha Fi Al-Madzahib Al-Arba`ah, 1st ed. (Damaskus: Dar al-Fikr, 2006)., hlm. 285.
} 
adalah layyin (lunak) dan inqiyad (mudah diatur). Sedangkan dalam istilah maknanya sesuai dengan makna bahasanya. Sebagaimana dalam al-Qur'an surat al-Qamar: 54 " dalam ayat lain juga disebutkan dalam surat al-Baqarah: 280 " وان كان ذو عسرة "Dalam kaitannya dengan taysir ini terdapat lafadz takhfiif (keringanan) dan tarkhis (dipensasi), kedua lafadz tersebut lebih khusus dari pada taysir. Takhfif (keringanan) itu ketika taklif (beban ibadah) dirasakan berat maka diberi keringanan untuk memudahkan melakukannya. Sedangkan tarkhis ketika terdapat alasan atau udzur untuk tidak melakukannya, maka didispensasi karena alasan tersebut. ${ }^{7}$

Rukhsoh (keringanan) secara bahasa diartikan sebagai layin (lembut), yusr (mudah), tawasssu' (longgar). Dikatakan dalam misbah al-munir al-rukhsoh yaitu tashil dan taysir (kemudahan), ketika syara memberi rukhsoh maka memberikan kemudahan bagi mukallaf. Sedangkan secara istilah hukum-hukum yang ditetapkan syara' berdasarkan udzur (alasan) yang memperbolehkan melakukan perbuatan yang dilarang berdasarkan adanya kesulitan atau kesusahan. ${ }^{8}$ Sedangkan macam-macam taysir (kemudahan) dalam syariat sebagaimana di jelaskan sebagai berikut: ${ }^{9}$

1. Kemudahan yang ditetapkan syari (Allah) terhadap syariat Islam, Islam merupakan agama yang telah ditetapkan kemudahannya sejak awal diturunkannya kepada Nabi Muhammad. Di mana Islam dibebankan kepada seorang laki-laki yang tidak mampu membaca dan menulis, namun al-Qur'an diturunkan kepadanya dengan mudah. Nabi saw yang sebelumnya tidak bisa membaca dan menulis dalam sekejap dimudahkan untuk dapat membaca dan menulis. Begitupun dengan al-Qur'an yang diturunkan kepadanya, sangat mudah untuk dibaca dan dipahami meskipun sastranya sangat tinggi dan bagus. Al-

\footnotetext{
${ }^{7}$ Wuzarat al Auqaf Wa al Syu un al Islamiyah, Al-Mausu 'ah Al-Fiqhiyah, 2nd ed. (Kuwait: Dzar al-Salasil, 1988),, hlm. 211.

${ }^{8}$ Al-Burnu, Al-Wajiz Fi Idhahi Qawaid Al-Fiqh Al-Kulliyah., hlm. 93.

${ }^{9}$ Wuzarat al Auqaf Wa al Syu un al Islamiyah, Al-Mausu'ah Al-Fiqhiyah., hlm. 214.
} 
Qur'an menjelaskan hal ini dengan "بسرناه بلسانكفانم" (QS. Maryam: 97) mudah untuk diucapkan dan diturunkan dalam sab atu ahruf untuk memudahkan manusia saat itu dan agar dapat mengucapkannya dengan mudah.

2. Kemudahan syari'at dalam hukum-hukum yang berkaitan dengan masalah amaliyah. Dalam hal ini terdapat dua macam kemudahan:

a. Al yusr al asli, kemudahan sebagai dasar dan tujuan syari'at. Sebagaimana yang sudah dijelaskan di atas tentang syariat Islam yang mudah. Adapun yang termasuk dalam yusr ini adalah pembebasan atau pengampunan beban bagi anak kecil dan orang gila dari hukum. Begitu juga kemudahan-kemudahan yang sudah jelas ditetapkan syara untuk kemaslahatan dan kebaikan

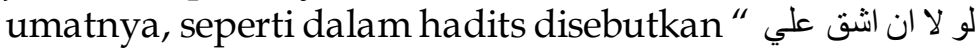
. dikeluarkan oleh Bukhari Muslim. Begitu juga dengan kewajiban sholat lima waktu menunjukkan syari at memudahkan umatnya hanya dengan lima waktu. Diceritakan dalam hadits Ibnu Majah, Nabi suatu saat ditanya oleh salah satu sahabatnya tentang haji, "apakah kewajiban haji itu setiap tahun?" Nabi menjawab "kalau saya jawab ya, maka kewajiban haji setiap tahun, dan kamu tidak akan sanggup, maka tinggalkan saja apa yang tidak aku perintahkan." Hal ini menunjukkan Islam membebankan kewajiban umatnya sesuai kemampuan dan tidak memberikan kesulitan bagi umatnya.

b. Al yusr al takhfifi, kemudahan sebagai dispensasi dan keringanan yang diberikan syara ketika mukallaf mengalami kesulitan dalam melaksanakan kewajiban. Maka mukallaf diberi keringanan untuk melaksanakan kewajibannya sesuai kemampuan. Takhfif merupakan hukum baru yang terlahir dari hukum asal. Takhfif disyari'atkan untuk kepentingan manusia dalam menghadapi dharar (bahaya) atau kesulitan sebagai 
alasan untuk memilih melakukan atau meninggalkan perintah syara'.10

Para Ulama' berpendapat bahwa segala keringanan ( $r u k h s o h)$ masuk dalam kaidah ini. Sedangkan sebab-sebab keringanan itu sendiri adalah sebagai berikut:11

1. Bepergian, dalam hal ini orang yang bepergian mendapatkan keringanan untuk tidak melakukan ibadah seperti

2. Sakit, dalam kategori sakit yang bisa memberikan keringanan hukum bagi seorang muslim adalah sakit yang sudah melampaui batas kemampuan dan tidak bisa lagi di tolerir.

3. Ikrah (paksaan), pemaksaan berarti adanya unsur ketiga yang memaksa, yaitu adanya ancaman yang akan mengakibatkan bencana atau bahaya bagi diri ataupun harta orang yang dipaksa tersebut. Dalam hal ini pemaksaan terbagi dalam dua bentuk, mulji yaitu pemaksaan yang berkaitan dengan hal-hal yang mengakibatkan kerusakan, tanpa bisa terganti, seperti hilangnya anggota jiwa atau nyawa atau rusaknya harta benda dan ghairu mulji adalah sebaliknya, pemaksaan hanya sebatas menghilangkan keridhaan seseorang, tidak sampai mengancam hilangnya jiwa atau harta benda 12

4. Lupa, yaitu ketika seseorang tidak dapat mengingat apa yang semestinya dilakukan, baik dalam ibadah ataupun yang lainnya. Seperti halnya orang yang berhutang lupa untuk membayarnya, maka bagi da in (yang menghutangi) memperingatkannya dan tidak boleh meminta denda. Kecuali ada unsur kesengajaan bagi pihak madin (penghutang).

5. Kesulitan dan Umum al-Balwa, seperti halnya diperbolehhkan ba`i wafa, muzara $a h$, musaqah, salam dan ijaroh.

${ }^{10}$ Ibid., hlm. 226.

${ }^{11}$ Jalaluddin Al-Suyuti, Al-Asybah Wa Al-Nadhair Fi Qawaid Wa Furu'AlSyafi iiyah, 1st ed. (Kairo: Dar al-Salam, 2006)., hlm. 196.

12 Al Zarqa', Muhammad, Syarh al Qawaid al fiqhiyah, (Damaskus : Dar al Qalam, 1989), hlm. 158. 
6. Naqs (sifat kurang/lemah), seperti anak kecil yang tidak diwajibkan berpuasa, wanita haid, nifas, orang gila. Sebagaimana tidak diwajibkannya seorang perempuan dalam jihad dan kewajiban lain yang diwajibkan bagi lakilaki.

7. Jahl (ketidaktahuan), tidak adanya pengetahuan tentang apa yang semestinya diketahui. Seperti dalam jual beli terdapat cacat, ketika di awal pembelian tidak diketahui ada cacat, maka bagi pembeli diberikan hak khiyar untuk mengembalikannya sesuai dengan kesepakatan. Kejahilan terdapat empat macam:

a. Kejahilan yang bathil; tidak mendapatkan udzur ketika di akhirat seperti kejahilan kafir terhadap sifat-sifat Allah dan hukum-hukum akhirat. Jahl mengikuti hawa nafsu, jahl pemberontak, jahl berpaling dari ijtihad dari al-Qur'an dan sunah masyhurah dan ijma'.

b. Kejahilan yang tidak tahu mengenai ijtihad yang benar, maka terkena $u d z u r$. Seperti orang yang menzinai budak dan anaknya atau istrinya dia menyangka hal tersebut diperbolehkan.

c. Kejahilan pada Negara yang belum berlaku hukum Islam. Misalnya, minum khamr tidak mendapatkan sanksi karena kebodohan tersebut.

d. Kejahilan Syafii'

1) Kepayahan: tanaman yang terkena najis binatang yang membajaknya dimaafkan. Atau misalnya dibolehkan istinja' dengan batu, kebaikan memakai sutra bagi laki-laki yang sakit, jual beli dengan akad salam, adanya khiar dalamjual beli dan shalat dengan najis yang sulit untuk dihilangkan.

2) Kekurangan: orang gila dan bayi tidak diberikan tanggungjawab oleh syara'. Misalnya wanita kadangkadang haid dalam setiap bulannya maka diperingankan untuk tidak mengikuti shalat jum'at, karena shalat jum'at membutuhkan waktu lama dan 
dikhawatirkan dalam kondisi jum'at itu datang bulan. ${ }^{13}$

Menurut pendapat Syeikh 'Izz al-Din bin Abd al-Salam alSyafi'i, jenis keringanan atau rukhsah itu ada enam.14 Manakala menurut ulama mazhab Hanafi sebagaimana yang dijelaskan oleh Ibn Nujaym termasuk Al-Ala'i, rukhsah itu ada tujuh jenis yaitu:15

1. keringanan dengan menggugurkan kewajiban. Contohnya: Tidak wajib atau gugur shalat Jumaat karena ada halangan tertentu, digugurkan kewajiban sholat bagi wanita yang haidh dan nifas, dan digugurkan kewajipan haji dan umrah disebabkan keudzuran, atau wanita yang tidak mendapatkan mahram.

2. keringanan dengan mengurangkan bebanan. Contohnya: Memendekkan atau qasar shalat dzuhur atau ashar menjadi dua rakaat ketika dalam perjalanan.

3. keringanan dengan gantian atau penukaran. Contohnya: Diganti ibadah dengan ibadah, seperti mengganti wudhu' dan mandi dengan bertayamum ketika tidak air atau tidak mampu untuk memakainya, mengganti puasa di lain waktu karena tidak mampu, menukarkan kedudukan shalat bagi orang sakit yang tidak berdiri dengan duduk atau berbaring atau isyarat, serta menukarkan bagi orang tua yang $u d z u r$ yang tidak dapat berpuasa dengan membayar fidyah.

\footnotetext{
${ }^{13}$ Al-Suyuti, Al-Asybah Wa Al-Nadhair Fi Qawaid Wa Furu`Al-Syafi iiyah., hlm. 56-57.

${ }^{14}$ Izz al-Din Al-Salam, Al Qawaid Al-Kubra (Damaskus: Dar al Qalam, 2000)., hlm. 12.

${ }^{15} \mathrm{Ab}$. Latif Muda and Rosmawati Ali, Perbahasan Kaedah-Kaedah Fiqh (Kuala Lumpur: Pustaka Salam Sdn. Bhd., 2000)., hlm. 150.
} 
Konsep Rukhsoh dan Relevansinya dengan Kaidah Al-Masyaqqah Tajlib Al-Taysir

4. keringanan dengan mendahulukan. Contohnya: Menyegerakan membayar zakat sebelum waktu atau haulnya dan shalat jama' taqdim.

5. keringanan dengan mengakhirkan. Contohnya: Menangguhkan puasa Ramadhan karena musafir, wanita haidh, wanita nifas dan shalat dengan jama' ta'khir serta menangguhkan shalat demi menyelamatkan orang mati lemas dan terbakar.

6. تخفيف

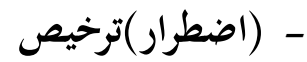

keringanan

mendapat rukhsah kerana terdesak atau terpaksa. Contohnya: Minum arak karena terlalu dahaga (haus) dan karena tidak ada air serta diharuskan makan bangkai karena terdesak, jika tidak melakukannya maka akan menyebabkan kematian.

7. keringanan mengubah atau menukar. Contohnya: Menukar dan mengubah kedudukan serta cara mendirikan shalat ketika dalam keadaan ketakutan dan menghadapi musuh.

Imlementasi dan Implikasi Konsep Rukhsoh dalam Kaidah AlMasyaqqah Tajlib Al-Taysir pada Peraturan OJK Nomor 11/POJK.03/2020 dan Surat Edaran Nomor S-9/D.05/2020

Peraturan OJK Nomor 11/POJK.03/2020 tentang stimulus perekonomian nasional sebagai kebijakan countercycial dampak penyebaran coronavirus disease 2019 dan Surat Edaran Nomor S9/D.05/2020 tentang kebijakan countercyclical dampak penyebaran coronavirus disease (Covid-19) bagi perusahaan pembiayaan merupakan salah satu upaya yang dilakukan pemerintah untuk tetap menjaga stabilitas ekonomi dalam kondisi saat ini. Kondisi yang menuntut beberapa daerah melakukan lockdown (karantina wilayah), perkantoran dan sekolah dialihkan secara virtual di rumah, pusat-pusat perbelanjaan dan UMKM terpaksa ditutup, serta adanya himbauan social distancing bahkan physical distancing. Pada bidang pendidikan misalnya, telah dikeluarkannya kebijakan penghapusan UN oleh Kemendikbud, perpanjangan semester 
mahasiswa yang terancam drop out (DO) oleh kemendikbud serta dispensasi potongan SPP dan perpanjangan pembayarannya yang diberikan oleh beberapa kampus swasta.

Dari penjelasan di atas, terlihat dampak yang dimunculkan oleh konsep rukhsoh dalam kaidah al-Masyaqqah tajlibu al-Taysir dalam penetapan kebijakan pemerintah untuk menangani pandemi covid-19 ini. Dampak ini terlihat ketika pemerintah memberikan berbagai macam stimulus kepada masyarakat baik terdampak maupun tidak. Seiring berkembanganya zaman dan teknologi, muncullah berbagai fenomena-fenomena baru khususnya dalam dunia kesehatan, covid19 ini misalnya. Virus ini baru dan perkembangannya masif, sehingga perlu penanganan tanggap darurat pula dari pemerintah pusat maupun daerah. Teks-teks syari'at juga telah menyiratkan dengan beberapa kisah terdahulu tentang adanya wabah penyakit (tho'un) di suatu Negeri.

Islam sebagai agama yang mudah, tidak membebankan umatnya untuk melangsungkan hidupnya dengan tetap beribadah. Dalam hal ini, konsep rukhsoh dalam kaidah al-Masyaqqah tajlibu alTaysir memberikan jawaban atas persoalan-persoalan tersebut di atas. Dengan melihat bahwa Islam menjunjung tinggi nilai kemanusiaan, bahkan pemeliharaan jiwa lebih utama dibandingkan pemeliharaan agama itu sendiri. Karena kondisi dunia dan Indonesia saat ini merupakan keselamatan dan hajat orang banyak dan hajat bisa menempati tempatnya dharurah. Ketika terdapat dharurah maka hukum yang diambil adalah yang ringan, begitupun ketika ditemukan masyaqqah (kesulitan) maka mengambil rukhsoh seimbang dengan melakukan 'azimah. Dalam hal ini pemerintah sebagai amri dan pemangku kebijakan tersebut diperbolehkan membuat kebijakankebijakan sebagai bentuk takhfif (keringanan) bagi masyarakat.

Menghadapi kondisi perekonomian yang terdampak penyebaran virus Corona, OJK telah dan akan mengeluarkan berbagai kebijakan di sektor perbankan dan industri keuangan non bank (IKNB) antara lain:

1. Perpanjangan batas waktu penyampaian laporan berkala IKNB kepada OJK; 
Konsep Rukhsoh dan Relevansinya

dengan Kaidah Al-Masyaqqah Tajlib Al-Taysir

2. Pelaksanaan penilaian kemampuan dan kepatutan (fit and proper test) pihak utama IKNB dapat dilaksanakan melalui video conference;

3. Penetapan kualitas aset pembiayaan dan restrukturisasi pembiayaan, yaitu:

a. Penilaian kualitas pembiayaan hanya berdasarkan ketepatan pembayaran pokok dan/atau bunga untuk pembiayaan s.d Rp10 miliar;

b. IKNB yang menyalurkan pembiayaan dapat melakukan restrukturisasi terhadap debitur/nasabah yang terkena dampak penyebaran COVID-19, dengan mempertimbangkan hal-hal sebagai berikut:

1) Adanya proses dan kebijakan restrukturisasi dari pemberi pinjaman, bagi sumber pendanaan dalam bentuk executing;

2) Adanya proses dan kebijakan restrukturisasi dari pihak pemilik dana, dalam hal penyaluran pembiayaan dilaksanakan melalui joint financing dan channeling;

3) Adanya permohonan restrukturisasi debitur/nasabah yang terkena dampak penyebaran COVID-19; dan/atau

4) Adanya penilaian kebutuhan dan kelayakan restrukturisasi dari pihak IKNB;

c. Kualitas pembiayaan bagi debitur/nasabah yang terkena dampak penyebaran COVID-19 yang direstrukturisasi ditetapkan lancar sejak dilakukan restrukturisasi;

4. Dalam rangka perhitungan tingkat solvabilitas perusahaan asuransi atau tingkat pendanaan dana pensiun dengan program manfaat pasti, aset yang berupa surat utang dapat dinilai berdasarkan nilai perolehan yang diamortisasi; dan

5. Penundaan pelaksanaan ketentuan life cycle fund bagi dana pensiun yang menyelenggarakan program pensiun iuran pasti.

Selain hal-hal di atas, pemerintah bertangung jawab terhadap penduduknya yang terdampak berat covid-19 hingga hilangnya mata pencahariannya, dengan memberi kompensasi biaya hidup. Relaksasi kredit yang diberikan seperti dirincikan di atas dan kebijakan- 
kebjakan lain dari sektor pendidikan dan kesehatan, serta kompensasi biaya hidup yang diberikan pemerintah merupakan bentuk implementasi dari konsep rukhsoh dalam kaidah al-Masyaqqah tajlibu al-Taysir. Sebagaimana Majelis Ulama Indonesia dalam memberikan rukhsoh dalam beribadah pada kondsi penuh masyaqqah ini yang tertuang dalam beberapa fatwanya. Rukhsoh (keringanan) di sini tidak terbatas pada hal-hal syari'at atau ibadah saja, melainkan berlaku pada situasi saat ini, terlebih jika berbicara kemanusiaan. Negaranegara Barat saja menjunjung tinggi hak asasi manusia (HAM), begitupun ajaran agama Islam.

Selain itu, PT PLN (Persero) siap melaksanakan kebijakan pemerintah terkait pembebasan pembayaran listrik bagi 24 juta pelanggan dengan daya 450 Volt Ampere (VA). Lalu, memberikan diskon $50 \%$ bagi 7 Juta pelanggan dengan daya 900 VA bersubsidi. Keringanan biaya listrik ini akan berlaku selama tiga bulan yakni April, Mei, dan Juni 2020. Kemudian, pemerintah melalui Kementerian Kesehatan memberikan penggantian biaya perawatan pasien covid-19 kasus PDP, sedangkan penggantian pembiayaan layanan pasien covid-19 kasus OPD oleh Pemerintah Daerah dengan standar pembiayaan INA-CBGs. Kebijakan tersebut sejalan dengan konsep rukhsoh dan selaras dengan tujuan syari' at (maqashid syari'ah) yakni, pemeliharaan jiwa, pemeliharaan harta, dan pemeliharaan keturunan. Bagaimanapun setiap orang wajib melakukan ikhtiar menjaga kesehatan dan menjauhi setiap hal yang dapat menyebabkan terpapar virus corona (covid-19) karena hal itu merupakan bagian dari menjaga tujuan pokok beragama (al-dharuriyat al-khams).

\section{Kesimpulan}

Al-masyaqqah menurut bahasa (etimologis) merupakan al$t a^{\prime} a b$ yaitu kelelahan, kepayahan, kesulitan, dan kesukaran. Sedangkan kata al-taysir secara bahasa (etimologis) adalah kemudahan. Seperti di dalam hadis Rasulullah saw disebutkan: "Sesungguhnya Agama itu mudah" (HR. Bukhari dan Muslim). Kaidah kesulitan itu dapat menarik kemudahan dimaksukan bahwa kesukaran menyebabkan adanya suatu kemudahan. Hukum yang pada praktiknya menyulitkan mukallaf dan pada diri dan sekitarnya terdapat kesulitan, maka syari'at memudahkannya sehingga beban tersebut berada di bawah kemampuan mukallaf tanpa kesulitan. 
Konsep Rukhsoh dan Relevansinya dengan Kaidah Al-Masyaqqah Tajlib Al-Taysir

Hukum rukhsah adalah hukum tentang keringanan yang dilakukan oleh seorang mukallaf karena adanya kesulitan.

Islam sebagai agama yang mudah, tidak membebankan umatnya untuk melangsungkan hidupnya dengan tetap beribadah. Dalam hal ini, konsep rukhsoh dalam kaidah al-Masyaqqah tajlibu alTaysir memberikan jawaban atas persoalan-persoalan saat ini. Dengan melihat bahwa Islam menjunjung tinggi nilai kemanusiaan, bahkan pemeliharaan jiwa lebih utama dibandingkan pemeliharaan agama itu sendiri. Karena kondisi dunia dan Indonesia saat ini merupakan keselamatan dan hajat orang banyak dan hajat bisa menempati tempatnya dharurah. Ketika terdapat dharurah maka hukum yang diambil adalah yang ringan, begitupun ketika ditemukan masyaqqah (kesulitan) maka mengambil rukhsoh seimbang dengan melakukan 'azimah.

Pemerintah sebagai amri dan pemangku kebijakan diperbolehkan membuat kebijakan-kebijakan sebagai bentuk takhfif (keringanan) bagi masyarakat sebagai bentuk stimulus bagi masyarakat dampak covid-19 seperti yang tertuang dalam Peraturan OJK Nomor 11/POJK.03/2020 tentang stimulus perekonomian nasional sebagai kebijakan countercycial dampak penyebaran coronavirus disease 2019 dan Surat Edaran Nomor S-9/D.05/2020 tentang kebijakan countercyclical dampak penyebaran coronavirus disease (Covid-19) bagi perusahaan pembiayaan.

\section{Daftar Pustaka}

Al-Burnu, Muhammad Shidqi bin Ahmad. Al-Wajiz Fi Idhahi Qawaid Al-Figh Al-Kulliyah. Beirut: Muassisah al-Risalah, 1996.

- - - Mausuah Al-Qawaid Al-Fiqhiyah. 9th ed. Beirut: Muassisah alRisalah, 2003.

Al-Salam, Izz al-Din. Al Qawaid Al-Kubra. Damaskus: Dar al Qalam, 2000.

Al-Suyuti, Jalaluddin. Al-Asybah Wa Al-Nadhair Fi Qawaid Wa Furu' Al-Syafi ïyah. 1st ed. Kairo: Dar al-Salam, 2006.

Al-Zuhaili, Muhammad. Al-Qawaid Al-Fiqhiyah Wa Tathbiqatuha Fi AlMadzahib Al-Arba `ah. 1st ed. Damaskus: Dar al-Fikr, 2006.

Deputi Komisioner Humas dan Logistik. SIARAN PERS: STABILITAS SEKTOR JASA KEUANGAN TETAP TERJAGA DI TENGAH MEREBAKNYA WABAH VIRUS CORONA. Jakarta, 2020. 
https://www.ojk.go.id/id/berita-dan-kegiatan/siaranpers/Pages/Siaran-Pers-Stabilitas-Sektor-Jasa-Keuangan-TetapTerjaga-di-Tengah-Merebaknya-Wabah-Virus-Corona.aspx.

Komisi Fatwa Majelis Ulama Indonesia. Fatwa MUI Nomor 17 Tahun 2020 Pedoman Kaifiat Shalat Bagi Tenaga Kesehatan Yang Memakai Alat Pelindung Diri (APD) Saat Merawat Dan Menangani Pasien Covid-19. Jakarta, 2020. https://mui.or.id/wpcontent/uploads/2020/03/Fatwa-MUI-Nomor-17-Tahun-2020tentang-shalatnya-tenaga-kesehatan-COVID-19.pdf.

Muda, Ab. Latif, and Rosmawati Ali. Perbahasan Kaedah-Kaedah Fiqh. Kuala Lumpur: Pustaka Salam Sdn. Bhd., 2000.

Salim, Abu Malik Kamal bin As-Sayyid. "Shahih Fikih Sunnah Lengkap." In Shahih Fikih As-Sunnah Wa Adillatuhu Wa Taudhih Madzahib Al A'immah. 1st ed. Jakarta: Pustaka Azzam, 2007.

Usman, Mukhlis. Kaidah-Kaidah Ushuliyah Dan Fighiyah. Jakarta: PT Raja Grafindo Persada, 1997.

Wuzarat al Auqaf Wa al Syu un al Islamiyah. Al-Mausu'ah Al-Fighiyah. 2nd ed. Kuwait: Dzar al-Salasil, 1988. 